\title{
The Estimation of Snow Cover Distribution Using Satellite Data in the Cold Arid Leh Region of Indian Himalaya
}

\author{
Mahesh K. Gaur ${ }^{*}$, R.K. Goyal' ${ }^{1}$ Dipankar Saha², Neelratan Singh ${ }^{3}$, \\ Shubhendu Shekhar ${ }^{4}$, Ajai ${ }^{5}$, J.S. Chauhan ${ }^{1}$ \\ ${ }^{1}$ ICAR-Central Arid Zone Research Institute, Jodhpur-342003. India \\ ${ }^{2}$ Regional Research Station, ICAR-Central Arid Zone Research Institute, Leh, India \\ ${ }^{3}$ Geochronology Group, Inter University Accelerator Centre, New Delhi, India \\ ${ }^{4}$ Department of Geology, Center for Advanced Studies, University of Delhi, India \\ ${ }^{5}$ Space Application Center, Ahmedabad, India
}

Received: 3 February 2021

Accepted: 8 April 2021

\begin{abstract}
Snow cover is an important feature for the supply of freshwater and influences climatic hydrology at various altitudes, especially in mountain regions. Snow is a significant component of the environmental threat. In order to map and realize the extent of snow cover at high altitudes, continuous monitoring is therefore necessary. Data from satellite remote sensing helps to capture land cover and changes in land cover. The major intricacies in the snow cover mapping in the Leh region are the underlying vegetation, debris, and sparse snow. The Landsat OLI satellite data base methodology was developed to map the snow cover in the Leh region of the Indian Himalayas through NDSI (normalized difference snow index) to overcome such area specific issues. NDSI encompasses a reasonably good accuracy and can be used extensively because topographic shadows, water bodies and clouds can easily be misinterpreted as snow. It is capable of differentiating pixels of snow from pixels of cloud, debris, vegetation, and water. The NDSI was generated for snow mapping using Landsat OLI satellite images. Using the high reflectance of the snow in the blue band, misinterpreted water bodies were removed. NDSI was subsequently used month-wise to estimate the snow cover of the Leh region (Ladakh Union Territory of India). The findings of present study clearly indicate that the accuracy of the NDSI is reasonably appropriate for the estimation of the snow cover distribution over a wider area. It has been also observed that the snow cover in the study region has decreased over the years.
\end{abstract}

Keywords: snow cover, NDSI, Landsat OLI and Sentinel-2a satellite images, Leh, Indian Himalayas

*e-mail: maheshjeegaur@yahoo.com 


\section{Introduction}

One tenth part of the Earth's surface is permanently covered with ice, but snow and ice is present across the world in unpredictable quantities during different seasons. In Himalayan region the traditional fieldbased methodology is not useful for the study due to its rough topography, extreme weather conditions and high altitude. The satellite data are used for accurate observations due to its synoptic view, generating distinct spectral properties of snow and glaciers, high temporal frequency assisted by advanced digital image processing and analytical techniques. Due to its unique and broad applicability Geographical Information System (GIS) and remote sensing (RS) tools and techniques have gained popularity to carry out accurate, swift cataloging, mapping and monitoring of the inaccessible terrain of Himalayan region [1]. A significant indicator of climate change is the process of ice forming and melting, and satellites play a crucial role in monitoring this [2]. Snow is a significant component of the Earth's radiation balance due to its unique reflective nature and broad surface exposure [3]. As such, during the winter Northern Hemisphere, snow covers more than 40 per cent of the surface of the Earth [4, 5]. Human activities in these regions are highly dependent upon their first date of first snowfall to ultimate melting. As the Cryosphere is constituted of diverse variables resulting the into foremost impact on geography, environment and their outcomes [6]. In hilly terrains, dissimilar hydrological snow indicators are difficult to measure and continue to change from point to point [7]. Different approaches have been offered for the identification of snow cover variations during the last few decades normalized difference indices such as normalized difference snow index (NDSI) $[8,9]$, change detection processes [10], pan-sharpening techniques [11], field observations or surface temperature based snow depth maps $[12,13,14]$ (Gusain et al., 2016; Singh et al., 2016; Taloor et al., 2019). Hall et al coined the term normalized-difference snow index (NDSI) in 1995 [15]. However, owing to different factors such as rough hilly terrain topography, prevalence of shadow effects and complex climatology, effective identification of snow cover variability is still a difficult task [16]. In various studies, satellite-based estimation of snow cover has been widely used in a number of recent climatehydrological studies. Most of these studies have been conducted at a local scale, such as explaining climate and erosion in the Himalayas [17] and detecting shifting mountain snow patterns [18]. As such the satellite remote sensing has been used for monitoring snowcovered areas because it can satisfy all of the necessary requirements namely, wide coverage, frequency, and simultaneity of measurements [19]. Also, snow is a critical factor in modelling and simulating alterations in climate change on the water resources, ecological factors, albedo, and ultimately the radiation budget changes $[20,21]$. Moreover, a combination of the green band and shortwave infrared-2 (SWIR2) band has been applied to map snow cover and water bodies, respectively [22]. Seasonal snowfall covers larger areas, particularly in the winter season whereas snowfall in the spring and summer seasons determines the flow of the rivers. During the winter season, the snow cover may cause avalanches to form, leading to hazards. Therefore, mapping the seasonal snow cover in the Leh area is also an important parameter for varied snowhazard applications. The analysis of the necessary algorithm to choose an appropriate sensor has also been studied by using capacity of remote sensing for the collection of required parameters in snow-hydrology $[23,24]$. However, because of its high reflectance, the degree of snow cover can easily be detected in the visible and near-infrared (NIR) wavelength bands [25].

The Leh region is located at a high altitude and has a rugged topography that is mostly inaccessible, making it very difficult to obtain information about the snow-covered areas. Earth observation satellites offer great potential for monitoring the dynamics of snow at different levels of scale.

\section{Material and Methods}

Snow consists of tiny ice pieces which is just a coarse material. The process of precipitation of snow is known as snowfall. The density of fresh snow is $30-50 \mathrm{~kg} / \mathrm{m}^{3}$ whereas the density of firn is about $400-830 \mathrm{~kg} / \mathrm{m}^{3}$ and density of glacier ice is $830-910 \mathrm{~kg} / \mathrm{m}^{3}$. Firn is a crystalline or granular snow, especially on the upper part of a glacier, where it has not yet been compressed into ice. Once the snow survives for a minimum of one summer, it becomes firn and in many years, it becomes glacier ice. Due to remelting and recrystallization snow density increases and air spaces decreases in the ice crystals [26]. The extent of the snow cover for numerous climatological and hydrological applications is considered an important parameter.

Use of conventional methods for the seasonal snow cover mapping and monitoring is an arduous job, particularly under harsh climatic conditions and rugged topography of the Himalayas. Remote sensing is used to map and monitor seasonal snow cover because it covers a larger area with recording high temporal frequency data and making snow easily identifiable as it has unique signatures in optical remote sensing data. The normalized difference snow index (NDSI) is a widely used algorithm for the detection and estimation of snow cover [27]. NDSI is also used as a decision tree parameter for cloud cover assessment algorithms. According to physical principles of remote sensing, the NDSI is based on the fact that snow reflects visible light more than it reflects middle-infrared light [28]. The ratio of radiance values in VNIR $(0.68-0.76 \mathrm{~mm})$ and NIR or SWIR $(1.55-1.75 \mathrm{~mm})$ provides a method to discriminate snow and cloud cover [29]. A ratio was used of 1.6-0.754 $\mathrm{mm}$ channels to distinguish snow 
and cloud using a cloud physics radiometer with 0.754-1.64 mm channels [30]. An IR band was also used to test for surface temperature to distinguish snow and clouds. More-sophisticated application of band ratios as used with Landsat Thematic Mapper TM data was developed [31,32] and the normalized difference of TM bands $2(0.52-0.60 \mathrm{~mm})$ and $5(1.55-1.75 \mathrm{~mm})$ was introduced [33]. An automated mapping of snow and threshold tests was developed for the identification of shadowed snow, vegetation, cloud, and soil in sundrenched areas [34]. The NDSI approach for the mapping of snow cover became automated, after the introduction of MODIS in 1999, by using an algorithm that uses the NDSI along with a range of threshold tests.

In addition, NDSI has some recognised limits, in which snow can sometimes be confused with water, and lower NDSI thresholds are sometimes needed to properly identify snow covered forests. This implies that by integration with other assessment indices, NDSI efficiency can be enhanced.

As snow reflects strongly in the visible region and absorbs in SWIR, with the aid of the difference in the ratio of visible and SWIR bands, an NDSI image is generated to demarcate snow and non-snow features. NDSI is calculated using the following general equation:

$$
N D S I=\frac{\text { Green }-S W I R}{\text { Green }+ \text { SWIR }}
$$

\section{Regional Setting}

Ladakh is a mountainous area nestled in the Indian Himalayas. Ladakh means "land of high passes". Its altitude varies from 2,800 metres to 4,500 metres above sea level. However, several peaks are above 6,000 metres in the Ladakh mountain range (Fig. 1). Leh district has an area of $45,110 \mathrm{~km}^{2}$ and a population

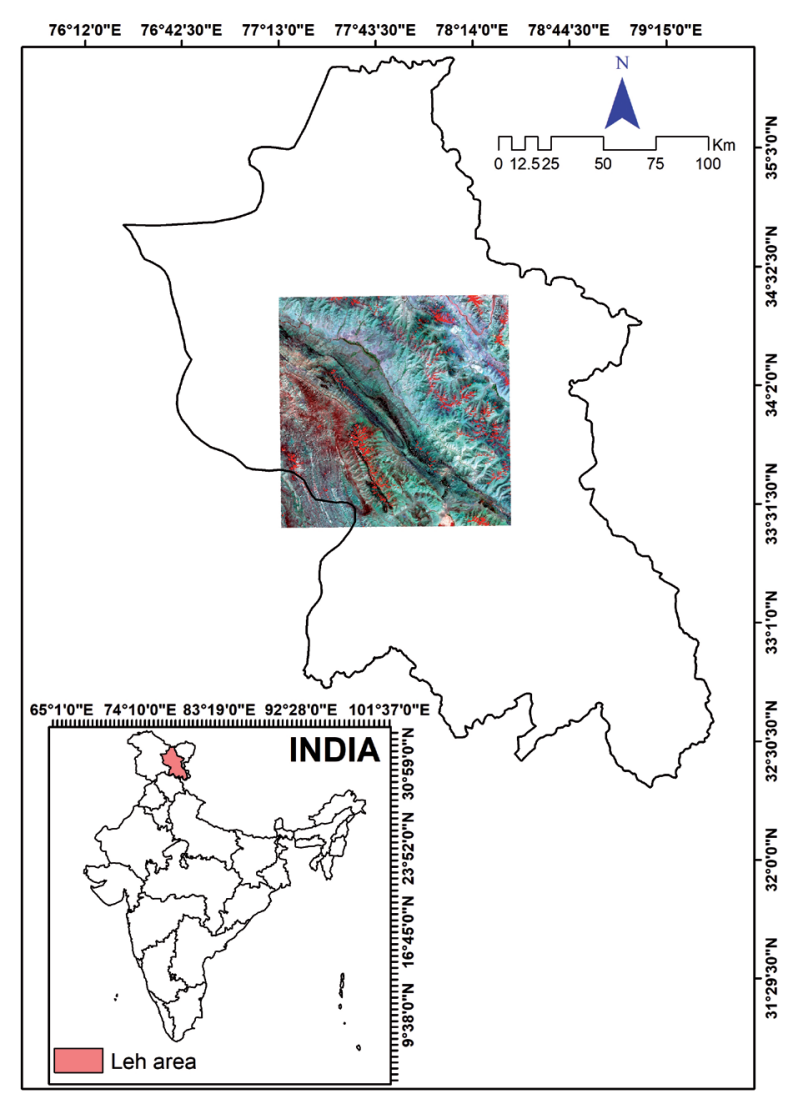

Fig. 1. Study area showing the studied Leh region in Ladakh mountain range.

density of only three persons per square kilometre. As the Himalayas, by generally refusing entry to monsoon clouds, build a rain shadow. Consequently, Ladakh is a desert at high altitudes [35]. Leh is the main town (population of 30870 in 2011 census) and it is located

Table 1. Specifications of the Sentinel-2A and Landsat 8 data.

\begin{tabular}{|c|c|c|c|c|c|c|}
\hline \multirow{2}{*}{$\begin{array}{l}\text { Spectral } \\
\text { Bands }\end{array}$} & \multicolumn{3}{|c|}{ Sentinel-2A } & \multicolumn{3}{|c|}{ Landsat-8 OLI } \\
\hline & Spectral Region & $\begin{array}{l}\text { Wavelength Range } \\
\text { (nm) }\end{array}$ & $\begin{array}{l}\text { Spatial Resolution } \\
(\mathrm{m})\end{array}$ & $\begin{array}{l}\text { Spectral } \\
\text { Region }\end{array}$ & $\begin{array}{l}\text { Wavelength Region } \\
\text { (nm) }\end{array}$ & $\begin{array}{l}\text { Spatial Resolution } \\
(\mathrm{m})\end{array}$ \\
\hline B1 & & & & Blue & $435-451$ & 30 \\
\hline B2 & Blue & $458-523$ & 10 & Blue & $452-512$ & 30 \\
\hline B3 & Green & $543-578$ & 10 & Green & $533-590$ & 30 \\
\hline B4 & Red & $650-680$ & 10 & Red & $636-673$ & 30 \\
\hline B5 & Red Edge & $698-712$ & 20 & NIR & $851-879$ & 30 \\
\hline B6 & Red Edge & $733-748$ & 20 & SWIR1 & $1566-1651$ & 30 \\
\hline B7 & Red Edge & $773-793$ & 20 & SWIR2 & $2107-2294$ & 30 \\
\hline B8 & NIR & $785-899$ & 10 & 冫 & & \\
\hline B8A & NIR Narrow & $844-875$ & 20 & & & \\
\hline B11 & SWIR & $1565-1655$ & 20 & & & \\
\hline B12 & SWIR & $2100-2280$ & 20 & & & \\
\hline
\end{tabular}




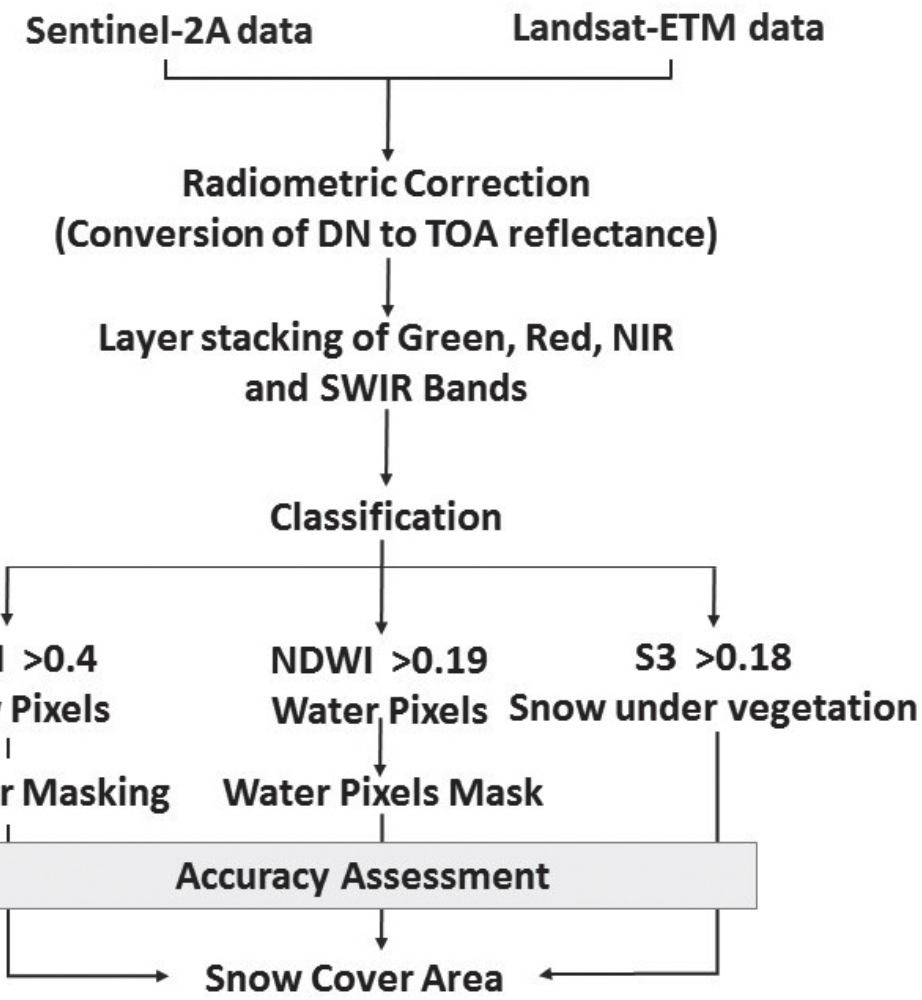

Fig. 2. NDSI Algorithm for Snow Cover Mapping.

at an altitude of 3,500 metres. The second largest city is Kargil which is situated at an altitude of 2,680 metres above sea level. Snowfall usually occurs in the months of December, January, February and March. Infrequent snowfall has also been recorded in the months of April, May, October and November till 2012 [36].

\section{Data and Methods}

The Landsat imagery obtained from Operational Land Imager (OLI), and Sentinel-2A has been extensively used in numerous studies in the field of remote sensing since their launch. It has been widely employed in inland water body and snow-cover mapping because of its high spatial resolution (http:// earthexplorer.usgs.gov). Landsat OLI and Sentinel data specifications are provided in Table 1.

After visually inspecting the output, the different Landsat-8 OLI and Sentinel-2A images will develop thresholds based on observed snow/ice characteristics. These outputs of the analysis show the following NDSI snow/ice thresholds: snow cover (high confidence), overcast (medium confidence) and low confidence (ground surface) areas (Fig. 2).

\section{Masking Based on Altitude}

Spectral overlap from various land-cover classes results in misclassification due to illumination. As a result, non-snow land cover appears as snow. Even scattered snow pixels were also observed in the tropical settings. Some pixels were misclassified as pixels of snow and were manually corrected. At the product level, there are limitations to addressing this issue. The altitude-based masking remains the single most widely used technique to deal with scattered snow pixels originating at low altitudes. The challenge lies in allocating the optimum threshold altitude to implement altitude-based masking throughout the region. Because of the heat released by the urban population of Leh, the snow line differs across the region, so there is no valid single threshold value. Therefore, different threshold values became necessary to use and snow pixels below threshold altitude were reclassified to surrounding land classes.

\section{Results and Discussion}

The snow reflectance is very high in the green and very low in the shortwave infra-red (SWIR) zones. In the SWIR zone, the ice absorption coefficient is very high, resulting in a very low reflectance in this spectrum region [37]. In the SWIR zone, on the other hand, water clouds and ice clouds are more reflective than snow [38], since water has less absorptive capacity than ice, and the tiny ice crystals in cirrus clouds are more reflective than the larger snow particles [39]. NDSI values were found to be in the range of 0.9 to 0.96 for all snow types, such as fresh, clean, patchy and muddy, and contaminated snow. Whereas the NDSI values for clouds, determined from the existing data 
of spectral reflectance [40] were found to be in the range 0.0 to 0.23 [41].

NDSI values for snow were found to be in the range 0.66 to 0.98 . Furthermore, the NDSI value for snow under the shadow of mountain is found to be around 0.92. This encourages the successful use of NDSI method for snow cover mapping and monitoring under mountain shadow. The NDSI values for the ground surface were considerably different from snow (range -1 to 0 ) while the vegetation could be delineated using the Red Band (0.63-0.69). However, water bodies have similar to snow NDSI values and must be masked while delineation of snow cover in the given NIR range of 0.76-0.90.

We computed the percentage of snow cover in both the NDSI images of Landsat and Sentinel and obtained the same result (Figs 3 and 4) This means that both images are equally reliable for the analysis of snow cover and that the snow cover is highest during the month of January, which gradually decreases until September-October months. It then increases again in the selected zone.

With the exception of snow and water, NDSI values for all other phenomenon such as soil, rock and vegetation typically confined in the Himalayas, are found to be less than zero. Water bodies have NDSI values that are identical to snow and required to be masked using an appropriate band during snow cover delineation. The water absorbs much of the radiation in the near-infrared region (NIR) and can therefore be easily delineated in the NIR band [42]. Fig. 5 demonstrates the NDSI classification of Sentinel-2 image (B3 and B11) as VIR and SWIR and Fig. 6 Landsat-8 Image using (B3 and B6) as Green and SWIR respectively. Month wise, Landsat-8 image and Sentinel-2 image data of 2019 and 2020 were used for the classification.

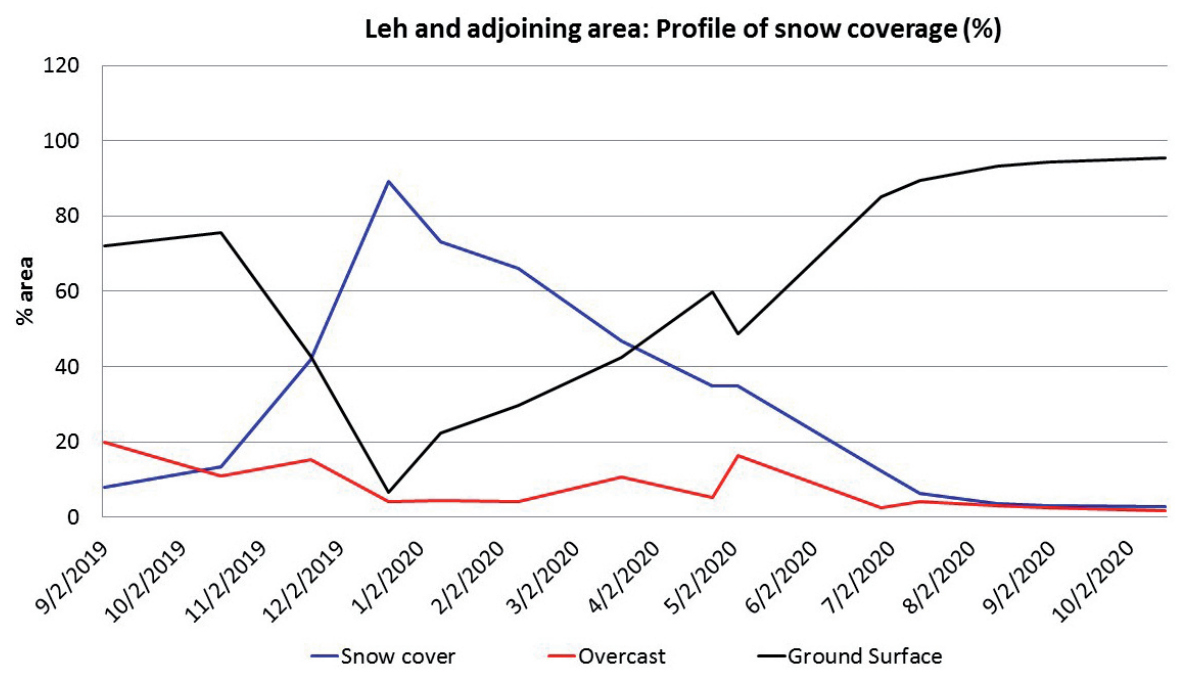

Fig. 3. Variation in snow cover (\%) areal extent from September 2019 to September 2020 (NDSI of Sentinel images).

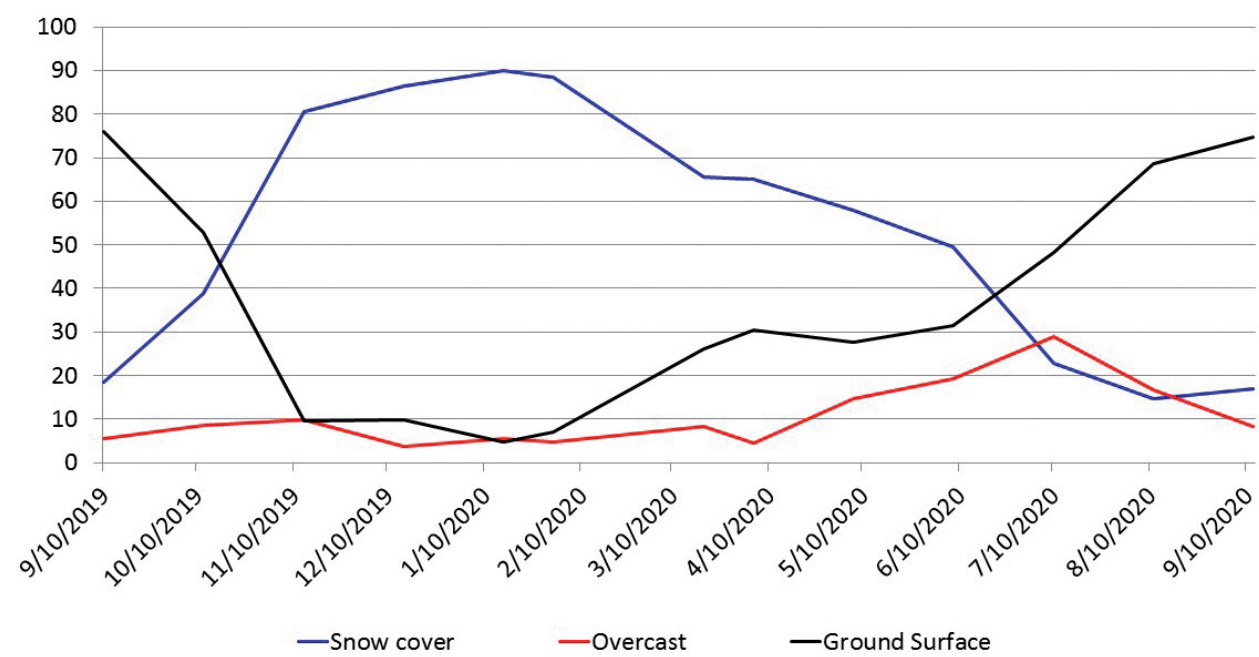

Fig. 4. Variation in snow cover (\%) areal extent from September 2019 to September 2020 (NDSI of Landsat-8 OLI images). 

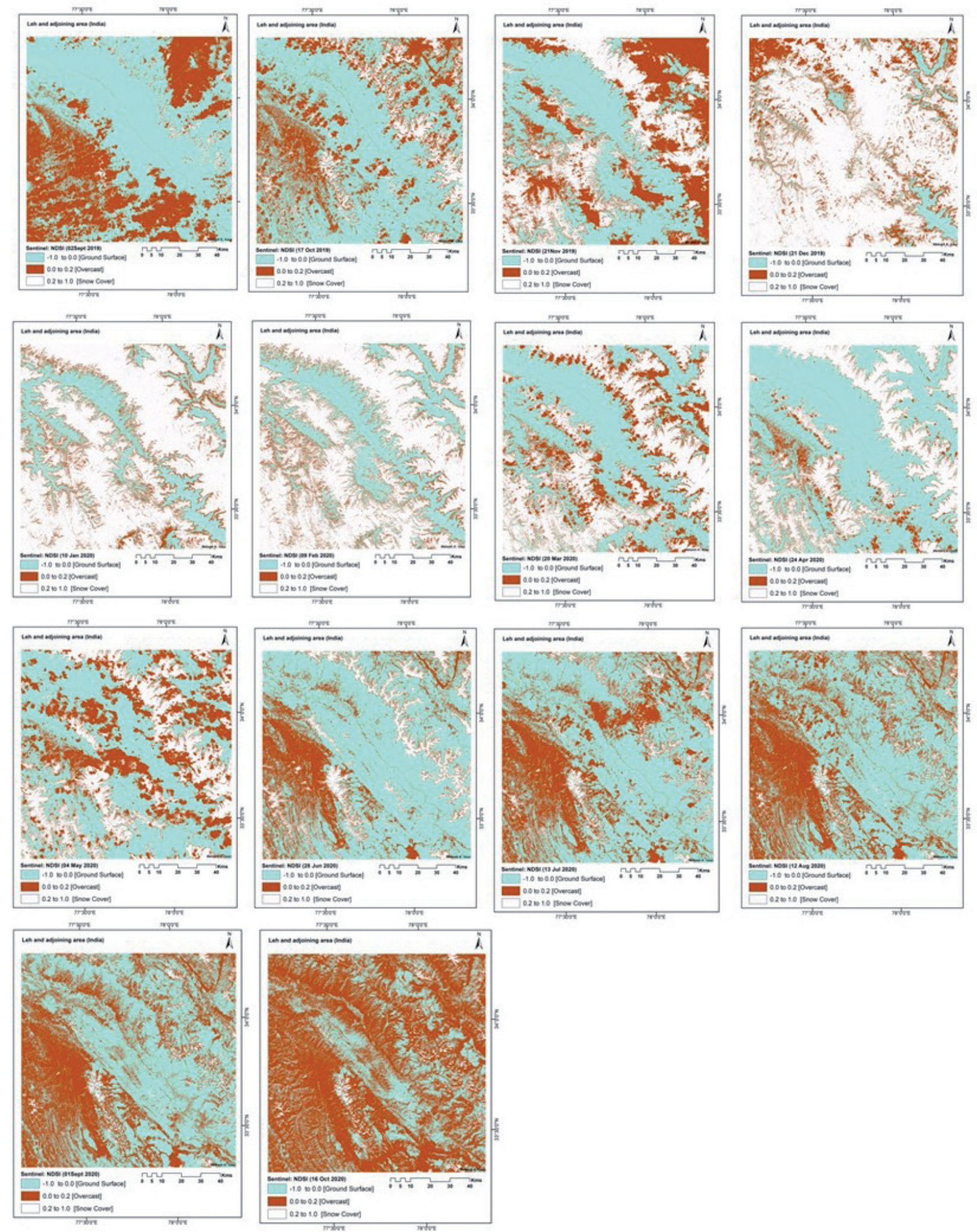

Fig. 5. Snow cover products (Sentinel-2A images, Sept. 2019 to Oct., 2020). 

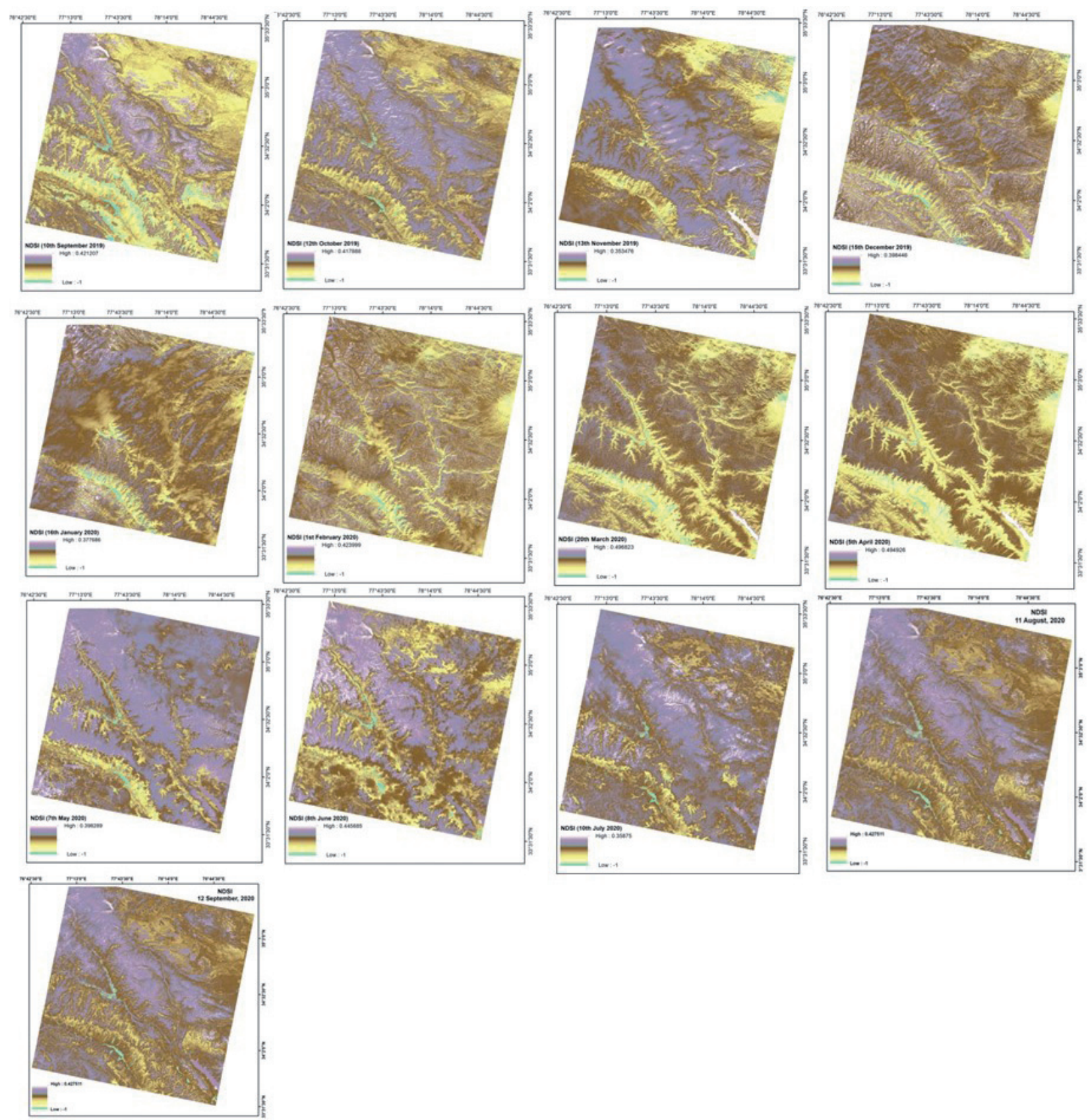

Fig. 6. Snow cover products (Landsat-8 OLI images, Sept. 2019 to Sept., 2020).

\section{Visual Identification of Snow and Cloud from Landsat 8 (Different Band Combination)}

In this analysis, the cloud particle and snow cover area were visually identified using different band combinations of Landsat 8 data (Fig 6). Although the cloud and snow spectral profile image can be clearly distinguished (Fig. 7).

\section{Assessment of Accuracy}

The error matrix approach has been used for determining accuracy. This approach allows quantitatively comparing of two sources of spatial information using a standard, non-site specific, and reliable accuracy assessment method [43]. This is achieved as on to a classified image (12-day enhanced Sentinel-2A snow product), information from the field station (snow or non-snow) is superimposed and the agreement between the information from the reference points and classified images are compared. The Cohen's Kappa statistics allows for chance, and ranges from 0 in the case of the most confused classification to 1 in the case of the most accurate classification [44, 45]. Kappa statistics and Overall accuracy were calculated using the resulting error matrix. Overall accuracy - the total agreement and/or difference between the maps - was determined by dividing the total number of correct sample units by the total number of sample units in the Kappa 

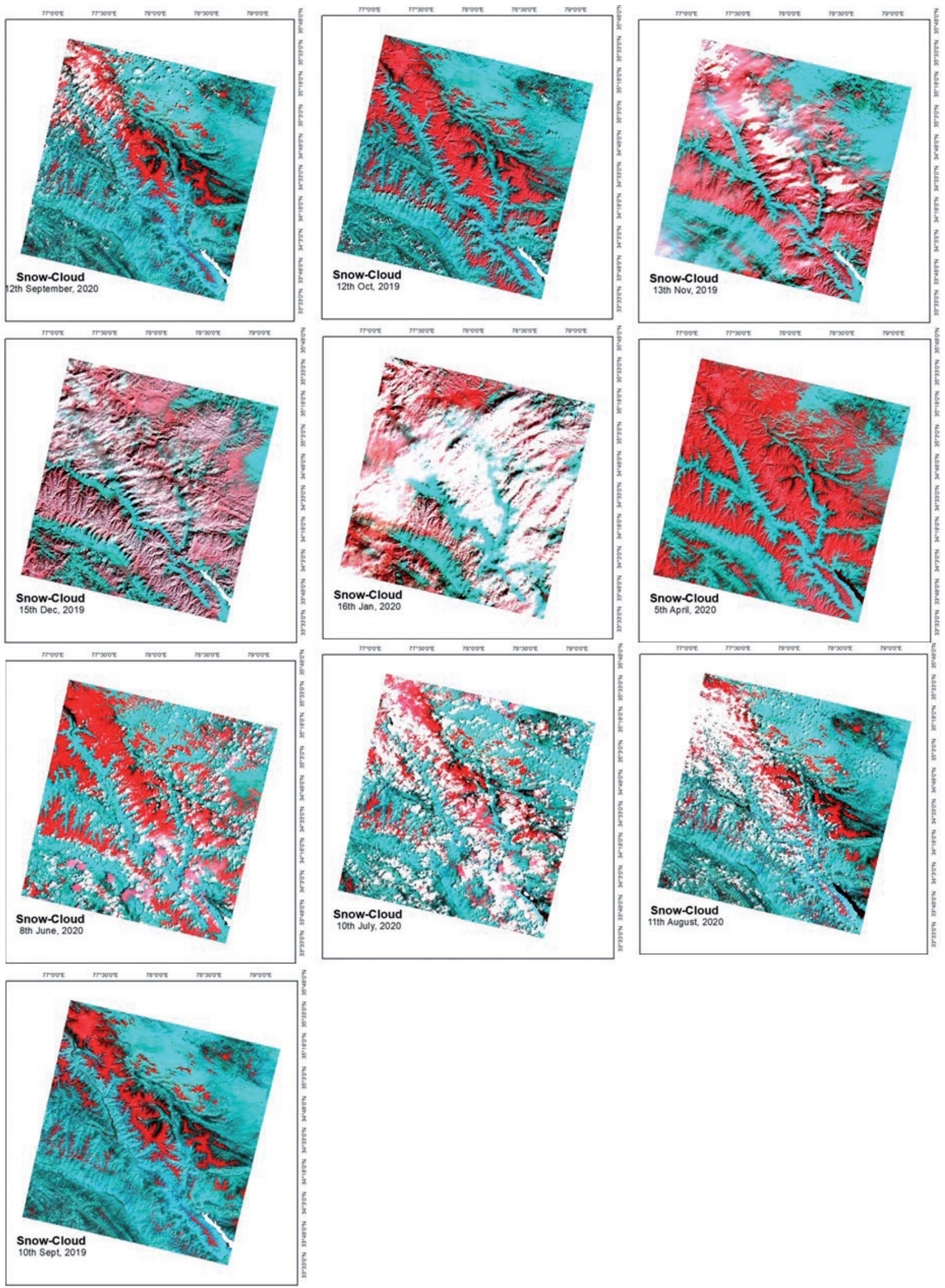

Fig. 7. Landsat 8 images of different band combination for snow and cloud identification. Bands $B_{7}, B_{6}, B_{2}(2019$ and 2020). It showing images cloud particles can be clearly identified in these images showing snow areas visually. 
statistics error matrix, which is a measure of the proportionate reduction of the error produced by the classification process compared to the error of a completely random classification [46].

$$
\text { Overall accuracy }=\frac{D}{N} \times 100 \%
$$

...where D denotes the total number of correct cells along the major diagonal and $\mathrm{N}$ the total number of cells in the error matrix.

Kappa coefficient $=N \sum_{i=1}^{r} \chi_{i i}-\sum_{i=1}^{r}\left(\chi_{i^{+}} X \chi_{+i}\right) / N^{2-} \sum_{i=1}^{r}\left(\chi_{i^{+}} X \chi_{+i}\right)$

Where $r$ is the number of rows within the matrix, $x_{i i}$ is the total number of correct cells in the very class (i.e., value in row $i$ and column $i$ ), $x i_{+}$is the total for row $i$, $x_{+i}$ is the total for column $i$, and $N$ is the total number of cells within the error matrix. The Erdas Imagine 2015 was used to determine error matrix. The accuracy assessment was performed in order to assess accuracy of each class. For these reasons, a reference data set containing a total of 396 points was initially developed. The overall accuracy for Landsat- 8 data was found to be $82.54 \%$ with a Kappa value of 0.8941 ; while the overall accuracy for Sentinel-2 data was $94.75 \%$ with a Kappa value of 0.9265 .

\section{Conclusions}

By using the Landsat- 8 and Sentinel-2A sensor data over the Leh area of India, snow cover distribution characteristics are calculated. To estimate the NDSI, the Landsat-8 and Sentinel-2A satellite sensor has the needed wavelength bands. However, because Sentinel-2 has similar spectral and spatial characteristics to Landsat OLI [47], their data were combined in the previous studies in order to achieve a better temporal observation [48, 49]. It was observed that the NDSI values remain stable with slope and aspect variations $[50,51]$. The NDSI, therefore, is suitable for the snow cover mapping. The results suggest the capability of NDSI based approach is to discern snow and non-snow regions under the mountain shadow, a very common problem during the winter period in the seasonal snow cover mapping. In addition, it is also established that there is a wide contrast between the NDSI values of snow and clouds and they can, therefore, be easily discriminated on a NDSI image. The present study is able to demonstrate the usefulness of the NDSI to establish a snow cover monitoring method as it is able to generate simultaneous outputs in the green and SWIR bands [52]. NDSI values are greater than 0.9 for all snow types, while the NDSI is less than zero for all other targets, except water. Due to higher spatial resolution, Landsat- 8 and Sentinel-2 optical images provides good results for the smaller areas. For the extraction of snow features from optical data, snow has different reflectance than other objects in these snow-clad regions. In the NDSI results corroborated the 0.4 as threshold, most commonly used as ideal for mapping snow. In the applications of cryohydrology, such as long-term and short-term runoff forecasts, the optimum information was ensured by the mixture of a passive sensor for the mapping of dry snow, water equivalent and snowmelt onset and active sensors for the mapping of wet snow with high areal resolution $[53,54]$. The accuracy assessment of Sentinel-2 optical image supervised classification was compared and it was computed to be 94.75 percent. The Landsat- 8 image illustrated a snow and ice accuracy was found at $82.54 \%$. Comparatively, temporal changes of 2019 to 2020 pertaining to snow and ice indicate a small decrease in the snow cover area with peaks during the months of December-January.

\section{Conflict of Interest}

The authors declare no conflict of interest.

\section{Acknowledgment}

Authors wish to express sincere gratitude to their respective organisations for providing facilities to conduct this research. We would also like to thank all the anonymous reviewers and editor for the critical comments to ensure the quality of the manuscript. Support received from the staff is thankfully acknowledged.

\section{References}

1. SAC. Monitoring Snow and Glaciers of Himalayan Region, Space Applications Centre, ISRO, Ahmedabad, India, 413, 2016.

2. OLSSON J., ARHEIMER B., BORRIS M., DONNELLY C., FOSTER K., NIKULIN G., YANG W. Hydrological climate change impact assessment at small and large scales: key messages from recent progress in Sweden. Climate, 4, 39, 2016.

3. DONMEZ C., BERBEROGLU S., CICEKLI S.Y.. SEVIM YASEMIN, CILEK A., ARSLAN A.N. Mapping snow cover using landsat data: toward a fine-resolution waterresistant snow index. Meteorology and Atmospheric Physics, 2020.

4. ESA. Clearest evidence yet of polar ice losses. http://www. esa.int/Applications/Observing_the_Earth/Space_for_ our_climate/Cleares t_evidence_yet_of_polar_ice_losses. $201 \overline{2}$.

5. ESA. European Space Agency Data Hub. https://scihub. copernicus.eu/dhus/\#/home. 2019.

6. VERLEYEN E., SABBE K., HODGSON D.A., GRUBISIC S., TATON A., COUSIN S., VYVERMAN W. Structuring effects of climate-related environmental factors on 
Antarctic microbial mat communities. Aquatic Microbial Ecology, 59, 11, 2010.

7. ABUDU S., CUI C., SAYDI M., KING J.P. Application of snowmelt runoff model (SRM) in mountainous watersheds: A review. Water Science and Engineering, 5, 123, 2012.

8. SHARMA V., MISHRA V.D., JOSHI P.K. Topographic controls on spatio-temporal snow cover distribution in Northwest Himalaya. International Journal of Remote Sensing, 35, 3036, 2014.

9. RATHORE B.P., BAHUGUNA I.M., SINGH S.K., RAJAWAT A.S., BRAHMBHATT R. M., RANDHAWA S.S., JANI P., YADAV S.K.S. Trends of snow cover in western and West-Central Himalayas during 2004-2014. Current Science, 114, 800, 2018.

10. SINGH S., SOOD V., TALOOR A.K., PRASHAR S., KAUR R. Qualitative and quantitative analysis of topographically derived CVA algorithms using MODIS and Landsat- 8 data over Western Himalayas, India. Quaternary International, 2020.

11. SINGH S., SOOD V., PRASHAR S., KAUR R. Response of topographic control on nearest-neighbor diffusion-based pan-sharpening using multispectral MODIS and AWiFS satellite dataset. Arabian Journal of Geosciences, 13, 668, 2020.

12. GUSAIN H.S., MISHRA V.D., ARORA M., MAMGAIN S., SINGH D. Operational algorithm for generation of snow depth maps from discrete data in Indian Western Himalaya. Cold Regions Science and Technology, 126, 22, 2016.

13. SINGH K.K., DEWAII S.K., SINGH D.K., MISHRA V.D., KAUR M. Monitoring of snow surface temperature in North-West Himalaya using passive microwave satellite data. Indian Journal of Radio \& Space Physics, 45, 20, 2016.

14. TALOOR A.K., KOTLIA B., JASROTIA A.S., KUMAR A., ALAM A., ALI S., KOUSER B., GARG P.K., KUMAR R., SINGH A., SINGH B., JASROTIA R. Tectonoclimatic influence on landscape changes in the glaciated Durung Drung basin, Zanskar Himalaya, India: A geospatial approach. Quaternary International, 507, 262, 2019.

15. SINGH D.K., GUSAIN H.S., MISHRA V.D., GUPTA N., DAS R.K. Automated mapping of snow/ice surface temperature using Landsat- 8 data in Beas River basin, India, and validation with wireless sensor network data. Arabian Journal of Geosciences, 11, 1, 2018.

16. WANG X., WANG J., JIANG Z., LI H., HAO X. An Effective Method for Snow-Cover Mapping of Dense Coniferous Forests in the Upper Heihe River Basin Using Landsat Operational Land Imager Data. Remote Sensing, 7, 17246, 2015.

17. BURBANK D.W., BOOKHAGEN B., GABET E.J., PUTKONEN J. "Modern Climate and Erosion in the Himalaya." Comptes Rendus Geoscience, 344, 610, 2012.

18. DEDIEU J.P., LESSARD-FONTAINE A., RAVAZZANI G., CREMONESE E., SHALPYKOVA G., BENISTON M. Shifting Mountain Snow Patterns in a Changing Climate from Remote Sensing Retrieval. Science of the Total Environment, 493, 1267, 2014.

19. HAQ M.A., JAIN K., MENON K.P.R. Development of new thermal ratio index for snow/ice identification. International Journal of Soft Computing and Engineering, 1, 2231, 2012.

20. ROBINSON D.A., KUKLA G. Maximum surface albedo of seasonally snow covered lands in the northern
Hemisphere; Journal of Climate and Applied Meteorology, 24, 402, 1985.

21. HAEFNER H., SEIDEL K., EHRLER H. Applications of snow cover mapping in high mountain regions. Physics and Chemistry of the Earth. 22, 275, 1997.

22. HALL D.K., RIGGS G.A., SALOMONSON V.V. Development of methods for mapping global snow cover using Moderate Resolution Imaging Spectroradiometer (MODIS) data. Remote Sensing of Environment, 54, 127, 1995.

23. LI W., DU Z., LING F., ZHOU D., WANG H., GUI Y., SUN B., ZHANG X. A Comparison of Land surface water mapping using the normalized difference water index from TM, ETM + and OLI. Remote Sensing (Basel) 5, 5530, 2013.

24. DIETZ A.J., KUENZER C., GESSNER U., DECH S. Remote sensing of snow - a review of available methods. International Journal of Remote Sensing, 33, 4094, 2012.

25. KOUR, RETINDER; PATEL, NILANCHAL; KRISHNA, AKHOURI PRAMOD. Assessment of relationship between snow cover characteristics (SGI and SCI) and snow cover indices (NDSI and S3). Earth Science Informatics, 8, 317, 2015.

26. DANKERS RUTGER, JONG STEVEN M. DE. Monitoring snow-cover dynamics in Northern Fennoscandia with SPOT VEGETATION images, International Journal of Remote Sensing, 25, 2933, 2004.

27. SAC. Monitoring Snow and Glaciers of Himalayan Region, Space Applications Centre, ISRO, Ahmedabad, India, 413, 2016.

28. SHARMA R.C., TATEISHI R., HARA K. A new waterresistant snow index for the detection and mapping of snow cover on a global scale. International Journal of Remote Sensing, 37, 2706, 2016.

29. YAN D., HUANG C., MA N., ZHANG Y. Improved Landsat-Based Water and Snow Indices for Extracting Lake and Snow Cover/Glacier in the Tibetan Plateau. Water. 12, 1339, 2020.

30. VALOVCIN F.R. Snow/cloud discrimination, AFGLTR-76-0174, ADA 032385, 1976.

31. KYLE H.L., CURRAN R.J., BARNES W.L., ESCOE D.A cloud physics radiometer, Third Conference on Atmospheric Radiation, American Meteorological Society, 28-30 June 1978, Davis, California, 107, 1978.

32. DOZIER J. Remote sensing of snow characteristics in the southern Sierra Nevada, "Large Scale Effects of Seasonal Snow Cover," Proceedings of the Vancouver Symposium, August 1987, International Association of Hydrological Sciences, 166, 305, 1987.

33. DOZIER J. Spectral signature of alpine snow cover from the Landsat Thematic Mapper. Remote Sensing of Environment, 28, 9, 1989.

34. DOZIER J., MARKS D. Snow mapping and classification from Landsat Thematic Mapper data. Annals of Glaciology, 9, 1, 1987.

35. HODGE H.N. Ancient futures: learning from Ladakh. Random House, New York. 2013.

36. INDIA METEOROLOGICAL DEPARTMENT (IMD) Climatological table. 2015.

37. DOZIER J. Spectral signatures of snow in visible and near-IR wavelengths. Proc. 3rd International Colloquium on Spectral Signatures of Objects in Remote Sensing, Les Arcs, France, 16-20 Dec., 1985, ESA SP-247, 437, 1985.

38. BOWKER D.E., DAVIS R.E., MYRICK D.L., STACY K., JONES, W.T. Spectral reflectances of natural targets 
for use in remote sensing studies. NASA RP-1139, 191, 1985.

39. PIAZZI G., TANIS C.M., KUTER S., SIMSEK B., PUCA S., TONIAZZO,, A., TAKALA M., AKYÜREK Z., GABELLANI S., ARSLAN A.N. Cross-Country Assessment of H-SAF Snow Products by Sentinel-2 Imagery Validated against In-Situ Observations and Webcam Photography. Geosciences, 9, 129, 2019.

40. BORMANN K.J., WESTRA S., EVANS J.P., MCCABE M.F. Spatial and temporal variability in seasonal snow density. Journal of Hydrolology, 484, 63, 2013.

41. UĞUR AVDAN, GORDANA KAPLAN. Algorithm for Snow Monitoring Using Remote Sensing Data, Anadolu University Journal of Science and Technology A - Applied Sciences and Engineering, 18, 238, 2017.

42. JOSEPH G., NAVALGUND R.R. Remote sensing-physical basis and its evolution. Glimpses of Science in India, National Academy of Sciences, Allahabad, India, 357, 1991.

43. MURTAZA K.O., ROMSHOO S.A. Determining the suitability and accuracy of various statistical algorithms for satellite data classification. International Journal of Geomatics and Geosciences, 4, 585, 2014.

44. ROMSHOO S.A, RASHID I. Assessing the impacts of changing land cover and climate on Hokersar wetland in Indian Himalayas. Arabian Journal of Geosciences. 2012.

45. SHOWQI I., RASHID I., ROMSHOO, S.A. Land use land cover dynamics as a function of changing demography and hydrology. GeoJournal, 1, 2013.

46. SAC. Monitoring Snow and Glaciers of Himalayan Region, Space Applications Centre, ISRO, Ahmedabad, India, 413, 2016.

47. STOREY J., ROY D.P., MASEK J., GASCON F., DWYER J., CHOATE M. A note on the temporary misregistration of Landsat- 8 Operational Land Imager (OLI) and Sentinel-2
Multi Spectral Instrument (MSI) imagery. Remote Sensing of Environment, 186, 121, 2016.

48. ZHU Z., WANG S., WOODCOCK C.E. Improvement and expansion of the Fmask algorithm: Cloud, cloud shadow, and snow detection for Landsats 4-7, 8, and Sentinel 2 images. Remote Sensing of Environment, 159, 269, 2015.

49. NOVELLI A., AGUILAR M.A., NEMMAOUI A., AGUILAR F.J., TARANTINO E. Performance evaluation of object based greenhouse detection from Sentinel-2 MSI and Landsat 8 OLI data: A case study from Almería (Spain). International Journal of Applied Earth Observations, 52, 403, 2016.

50. BUTT M.J. Characteristics of snow cover in the Hindukush, Karakoram and Himalaya region using Landsat satellite data. Hydrological Processes, 26, 3689, 2012.

51. BUTT M.J. Exploitation of Landsat data for snow zonation mapping in the Hindukush, Karakoram and Himalaya (HKH) region of Pakistan, Hydrological Sciences Journal, 58, 1088, 2013.

52. GAUR MAHESH K., GOYAL R.K., RAGHUVANSHI M.S., BHATT R.K., PANDIAN M., MISHRA A., SHEIKH S.I. Geospatially extracting snow and ice cover distribution in the cold arid zone of India. International Journal of System Assurance Engineering and Management 11, 84, 2020.

53. METSÄMÄKI S., BÖTTCHER K., PULLIAINEN J., LUOJUS K., COHEN J., TAKALA M., MATTILA O., SCHWAIZER G., DERKSEN C., KOPONEN S. The accuracy of snow melt-of day derived from optical and microwave radiometer data - a study for Europe. Remote Sensing of Environment, 211, 1, 2018.

54. VISTE E., SORTEBERG A. Snowfall in the Himalayas: an uncertain future from a little-known past, The Cryosphere Discussions, 9, 441, 2015. 